Open Access

\title{
Strength characteristics of genetically different rice and coconut husk ash compacted shales
}

Ibrahim Adewuyi Oyediran* and Oluwafemi Festus Fadamoro

\author{
* Correspondence: \\ oyediranibrahim2012@gmail.com \\ Department of Geology, Faculty of \\ Science, University of Ibadan, \\ Ibadan, Federal Republic of Nigeria
}

\begin{abstract}
Background: The strength characteristics of two genetically different shales treated with both Rice Husk Ash (RHA) and Coconut Husk Ash (CHA) was evaluated to elucidate responses and effects, examine effectiveness of the additives with a view to ultimately provide economically viable and environmental friendly options for modification and hence stabilization.

Methods: 2 to $20 \%$ by weight of both RHA and CHA were separately added to Okitipupa (SW) and Enugu (SE) shales with the subsequent determination of Plasticity Index (PI), Maximum Dry Density (MDD), Optimum Moisture Content (OMC), Unconfined Compressive Strength (UCS) and California Bearing Ratio (CBR).

Results: RHA and CHA were found to possess pozolanic properties such that their addition to shale in modest amounts (not more than $10 \%$ by weight) has beneficial effect on the strength characteristics. Addition of RHA produced shales with reduced PI, higher UCS, increased MDD and more pronounced reduction in OMC when compared with the CHA stabilized shales. However in general, addition of 10 \% RHA and 6-10\% CHA brought about optimal effect on the geotechnical properties of shales and as such can be regarded as the optimum content.

Conclusions: These materials can thus serve as suitable alternatives to modify and stabilize problematic shale and hence help reduce construction costs, environmental hazards and ultimately bring about shales with improved geotechnical properties.

Keywords: Shale stabilization; Genetically different shales; Environmental friendly options; Pozolanic properties; Optimum content
\end{abstract}

\section{Introduction}

The absence of readily available suitable construction materials close to the site of need and high cost of haulage of other alternatives makes the need to seek ways of improving available unsuitable materials imperative. Shale is a problem soil, especially the soft non-indurate type, which Joel and Agbede (2008) indicated undergoes volumetric changes when subjected to changes in moisture content as a result of the annual rainy and dry season and also perhaps as a result of its clayey nature. They tend, to have low shear strengths and to lose shear strength further upon wetting or other physical disturbances like most clays (Mitchell 1986; Brooks 2009). Soft rocks and expansive soils are most often associated with non-durability (Gamble 1971; Ezeribe 1994),

\section{Springer}


foundation problems and structural failures (Holtz and Kovacs 1982; Coduto 1999; Punmia et al. 2005). Yagiz (2001) opined that shale is the most problematic weak rock that causes many problems in the field before and after construction or excavation. Many structures founded on or constructed with shale have either collapsed soon after construction or have been found to be defective or shown signs of failure (Abeyeskera et al. 1978; El-Sohby et al. 1987; Okogbue and Aghamelu 2010; Iorliam et al. 2012b, 2013). Nandi et al. (2009) noted that shales are often intensely fractured and weathered and have highly variable geotechnical characteristics, which cause significant construction problems and damage to civil structures each year. These problems may not be unconnected to the mineralogical framework of the shales as according to Akawwi and Al-Kharabsheh (2002) the swelling and shrinkage potential of soils are affected by mineralogical constituents and surrounding environment.

The rising and prohibitive costs associated with the use of well-known stabilizers such as lime and cement as well as environmental issues arising from their use has made them unpopular and hence the search for suitable replacements. Needless to say that haulage costs involved with transporting and replacing unsuitable materials on site, adds up to the problems and cannot be overlooked. Nearly all industrial activities lead to depletion of natural resources, and in the process may result in accumulation of byproduct and/or waste materials. In most areas, the disposals of these waste heaps have become problematic while in recent years there has been concerted effort and intensified research towards the use of these by-products and waste materials in construction (Hughes and Glendinning 2005; Madjo and Riskowiski 2004; Okafor and Okonkwo 2009; Oriola and Moses 2010; Agbede and Joel 2011; Iorliam et al. 2012a). Moreover, the proposed use of waste materials from agricultural and industrial activities may as well also help provide solution to waste disposal problems which have arisen from such activities and hence will possibly give rise to a win-win situation both in terms of economics and environmental health.

Rice is a very common and staple food in most parts of the world with so much waste generated from its production activities. Rice milling generates the product known as rice husk which surrounds the paddy grain. Della et al. (2002) indicated that the beneficiation of rice generates as by-product rice husk that corresponds to about $23 \%$ of its initial weight. During the milling of paddy, about $78 \%$ is received as rice, broken rice and bran while the remaining $22 \%$ is received as husk (Nagrale et al. 2012). Rice husk is characterized by low bulk density and high ash content (18-22\% by weight) and is used in the rice mills to generate steam used in the parboiling process and contains about $75 \%$ organic volatile matter, leaving $25 \%$ to be converted into ash through combustion. The burning of rice husk in air always leads to the formation of silica ash, which varies from gray to black depending on inorganic impurities and unburned carbon amounts (Krishnarao et al. 2001). Rice husk ash (RHA) contains around 85-90\% amorphous silica, therefore, for every $1000 \mathrm{~kg}$ of paddy milled, about $220 \mathrm{~kg}$ ( $22 \%$ ) of husk is produced and when the husk is burnt in the boilers, about $55 \mathrm{~kg}$ of RHA is generated (Eberemu 2011). It is estimated that about $10^{8} \mathrm{t}$ of RHA is produced annually worldwide (Nakoo 1999). Oyetola and Abdullahi (2006) observed that local milling is done mostly by women in the urban and rural areas of Nigeria, who use mainly firewood as heat source and as such $100 \%$ 
of the rice husk from the mill is left as waste causing pollution of environment and disposal problems.

The same situation applies to Coconut (Cocos Nucifera) which is cultivated in abundance along the coast line of many countries because it prospers in sandy, saline soil and in tropical climates and is a source of exchange earnings from export particularly in Nigeria. When coconuts are harvested, the husks are removed, thereby leaving the shell and the copra (meat). These husks are considered as waste materials and are usually dumped into refuse bins. Companies where this copra is used in food processing usually dispose this husk indiscriminately causing environmental nuisance. These materials are then burnt into ashes to produce the coconut husk ash. The coconut husk ash when dried contains cellulose, lignin, pentosans and ash in varying percentage.

Many researchers the world over have shown that agricultural waste materials can be put to great use (Mehta 1977; Govindarao 1980; Zhang and Malhotra 1996; Boateng and Skeete 1990; Nottidge et al. 2009; Ramezanianpour et al. 2009; Fattah et al. 2013). In developing countries like Nigeria however, these dignified wastes like forage, rice husk, coconut husk and by-products have not been known to have much economic use. In addition it is important to note that while some researchers including (Okafor and Okonkwo 2009; Amu et al. 2011a, b, 2012; Olarewaju et al. 2011) have shown improvement in geotechnical properties of lateritic and black cotton soils with some of these waste materials, little can be said on the influence on shale geotechnical properties and information is still scanty. Hence, the focus of this research work includes finding suitable means of waste re-use to solve problems relating to waste disposal and other environmental issues due to increasing environmental concern. In addition the need to preserve energy and resources by seeking ways to modify and improve the geotechnical properties of shale to make it suitable for use in construction works is explored. This is with a view to obtain positive results which will help lower construction costs associated with haulage and use of other well-known chemical additives not forgetting the issue of availability. Lastly, the work seeks to elucidate the difference in response to the two different additives by the two genetically different shales.

\section{Materials}

\section{Shale}

Shale outcrops from six locations (three each) from two different sedimentary geological terrains, Okitipupa (Dahomey Basin, southwestern Nigeria) and Enugu (Anambra Basin, southeastern Nigeria) were sampled. The SW and SE shales respectively exhibit gray and black colours. The properties of the shales (Table 1) show they possess amounts of fines ranging from 87 to $89 \%$ for Okitipupa (SW) and 93 to $94 \%$ for Enugu (SE). Casagrande chart classification shows they are inorganic shales of medium plasticity and hence compressibility while they (SW and SE shales) respectively have mean specific gravity values of 2.56 and 2.50 . These values are lower than that of potentially durable construction aggregates, which should have specific gravity value greater than or equal to 2.625 (Reidenouer 1970). In terms of chemistry, (Table 2) analyses show that $\mathrm{SiO}_{2}$ content is high in all the shales with values from 55.51 to $59.10 \%$. In terms of abundance $\mathrm{Al}_{2} \mathrm{O}_{3}, \mathrm{Fe}_{2} \mathrm{O}_{3}$ and $\mathrm{FeO}$ are next in abundance to $\mathrm{SiO}_{2}$ in the shales. $\mathrm{MgCO}_{3}$, 
Table 1 Geotechnical properties of studied shales

\begin{tabular}{|c|c|c|c|c|c|c|c|}
\hline \multirow[t]{2}{*}{ Geotechnical properties } & & \multicolumn{3}{|c|}{$\begin{array}{l}\text { Okitipupa shale } \\
\text { (SW) }\end{array}$} & \multicolumn{3}{|c|}{$\begin{array}{l}\text { Enugu shale } \\
\text { (SE) }\end{array}$} \\
\hline & & SW1 & SW2 & SW3 & SE1 & SE2 & SE3 \\
\hline \multirow[t]{3}{*}{ Grain size distribution } & Sand (\%) & 13.00 & 11.00 & 12.00 & 7.00 & 6.00 & 6.00 \\
\hline & Silt (\%) & 54.00 & 57.00 & 55.00 & 63.00 & 70.00 & 63.00 \\
\hline & Clay (\%) & 33.00 & 32.00 & 33.00 & 30.00 & 24.00 & 30.00 \\
\hline \multirow[t]{4}{*}{ Consistency limits } & Liquid Limit (\%) & 40.00 & 50.00 & 50.00 & 38.00 & 35.00 & 40.00 \\
\hline & Plastic Limit (\%) & 16.00 & 13.00 & 10.00 & 18.00 & 21.00 & 18.00 \\
\hline & Plasticity Index (\%) & 24.00 & 37.00 & 40.00 & 20.00 & 14.00 & 22.00 \\
\hline & Casagrande Chart Classification & \multicolumn{6}{|c|}{$\begin{array}{l}\text { Inorganic Shales of Medium Plasticity/ } \\
\text { Compressibility }\end{array}$} \\
\hline Other & Specific Gravity & 2.58 & 2.54 & 2.57 & 2.49 & 2.51 & 2.49 \\
\hline \multirow[t]{3}{*}{ Compaction parameters } & Level & \multicolumn{6}{|c|}{ Modified AASHTO } \\
\hline & Optimum Moisture Content (\%) & 12.30 & 14.90 & 14.70 & 12.00 & 13.30 & 11.70 \\
\hline & Maximum Dry Density $\left(\mathrm{kg} / \mathrm{m}^{3}\right)$ & 1870 & 1600 & 1900 & 1841 & 1944 & 1831 \\
\hline \multirow[t]{3}{*}{ Strength characteristics } & California Bearing Ratio (soaked) (\%) & 49.00 & 45.00 & 27.00 & 32.00 & 45.00 & 33.00 \\
\hline & California Bearing Ratio (unsoaked) (\%) & 61.00 & 55.00 & 45.00 & 45.00 & 58.00 & 46.00 \\
\hline & Unconfined Compressive Strength $\left(\mathrm{kN} / \mathrm{m}^{2}\right)$ & 21.75 & 41.00 & 60.93 & 81.80 & 100.20 & 70.70 \\
\hline
\end{tabular}

$\mathrm{MgO}, \mathrm{K}_{2} \mathrm{O}, \mathrm{CaO}, \mathrm{CaCO}_{3}, \mathrm{P}_{2} \mathrm{O}_{5}, \mathrm{Na}_{2} \mathrm{O}$ and $\mathrm{TiO}_{2}$ all have contents lower than $2 \%$ in all the analysed shales. The relatively high values of $\mathrm{Fe}_{2} \mathrm{O}_{3}$ and $\mathrm{FeO}$ in all the samples are thought to be as a result of the influence of the ferruginized overlying materials on the shale outcrops. $\mathrm{CaO}$ is relatively low since the shale samples do not show any association with calcitic and dolomitic rocks. Kaolinite (blue lines) was observed from $\mathrm{X}$-Ray diffraction (Fig. 1a and b) to be the most abundant clay mineral in the shales. The highest percentage of Kaolinite was observed in the SE shale including the presence of pyrite in its mineral assemblage while the SW shale contained some amounts of Albite. The d-spacing (interatomic spacing in angstroms) dictates the quantum of water that can be taking in by the mineral is indicated for each peak.

\section{Rice and coconut husk ash}

Rice and Coconut husks were respectively obtained from Badagry and Igbimo-Ekiti, southwestern Nigeria, and burnt in open air with the resulting ash sieved through sieve no.200. The fraction that passed through the sieve was collected and kept in air tight

Table $\mathbf{2}$ Chemical and mineralogical properties of studied shales

\begin{tabular}{|c|c|c|c|c|c|c|c|c|c|c|c|c|}
\hline \multicolumn{13}{|c|}{ Chemical composition (\%) } \\
\hline Sample label & $\mathrm{SiO}_{2}$ & $\mathrm{Al}_{2} \mathrm{O}_{3}$ & $\mathrm{Fe}_{2} \mathrm{O}_{3}$ & $\mathrm{FeO}$ & $\mathrm{MgCO}_{3}$ & $\mathrm{MgO}$ & $\mathrm{K}_{2} \mathrm{O}$ & $\mathrm{Na}_{2} \mathrm{O}$ & $\mathrm{P}_{2} \mathrm{O}_{5}$ & $\mathrm{TiO}_{2}$ & $\mathrm{CaCO}_{3}$ & $\mathrm{CaO}$ \\
\hline Okitipupa shale (SW) & 55.51 & 17.57 & 9.87 & 8.87 & 1.94 & 0.93 & 1.45 & 0.21 & 0.10 & 0.93 & 0.75 & 0.42 \\
\hline Enugu shale (SE) & 59.10 & 16.34 & 6.41 & 5.76 & 0.94 & 0.45 & 1.30 & 0.37 & 0.07 & 1.07 & 0.28 & 0.15 \\
\hline \multicolumn{13}{|c|}{ Mineralogical composition (\%) } \\
\hline \multicolumn{2}{|c|}{ Mineral type $\longrightarrow$} & \multicolumn{3}{|l|}{ Quartz } & \multicolumn{3}{|l|}{ Kaolinite } & \multicolumn{2}{|l|}{ Albite } & \multicolumn{3}{|l|}{ Pyrite } \\
\hline \multicolumn{2}{|l|}{ Okitipupa shale (SW) } & \multicolumn{3}{|l|}{49.22} & \multicolumn{3}{|l|}{39.55} & \multicolumn{2}{|l|}{11.23} & \multicolumn{3}{|l|}{-} \\
\hline \multicolumn{2}{|l|}{ Enugu shale (SE) } & \multicolumn{3}{|l|}{36.74} & \multicolumn{3}{|l|}{43.67} & \multicolumn{2}{|l|}{ - } & \multicolumn{3}{|l|}{18.29} \\
\hline
\end{tabular}




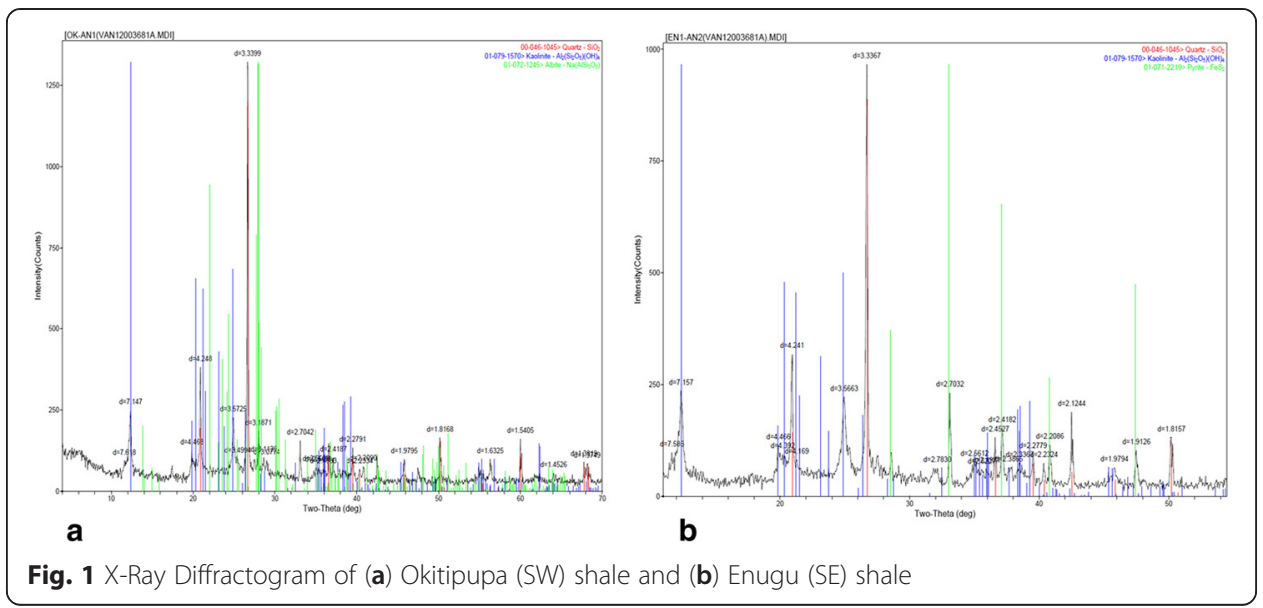

containers to avoid pre-hydration during storage. The chemical compositions of the Rice Husk Ash (RHA) and Coconut Husk Ash (CHA) indicate that the materials are mainly composed of $\mathrm{SiO}_{2}$ (Table 3). The chemical composition of ash to be used as pozzolans (pozzolanas are materials containing reactive silica and/or alumina which on their own have little or no binding property) should have a combined proportion of silicon dioxide $\left(\mathrm{SiO}_{2}\right)$, aluminium oxide $\left(\mathrm{Al}_{2} \mathrm{O}_{3}\right)$ and iron oxide $\left(\mathrm{Fe}_{2} \mathrm{O}_{3}\right)$ of not less than $70 \%$ as stipulated in ASTM C618 (1978) requirement. In addition, Loss on ignition (LOI) should not exceed $12 \%$. The combined proportion of silicon dioxide $\left(\mathrm{SiO}_{2}\right)$, aluminium oxide $\left(\mathrm{Al}_{2} \mathrm{O}_{3}\right)$ and iron oxide $\left(\mathrm{Fe}_{2} \mathrm{O}_{3}\right)$ for RHA (71.58 \%) and CHA (73.35 \%) used for this study shows they satisfy the requirement and hence possess pozolanic properties. In addition, the LOI of both the RHA (8.24) and CHA (9.34) are less than the maximum $12 \%$ required. Moreover the magnesium oxide $(\mathrm{MgO})$ content in both RHA (0.514) and CHA (0.015) are far less than the maximum $4 \%$ required value.

\section{Methodology}

The shales, Okitipupa (SW) and Enugu (SE) were air-dried for 3 weeks as opposed to the faster oven drying to obtain reliable results (because some clays undergo

Table 3 Chemical properties of Rice husk Ash (RHA) and Coconut husk Ash (CHA)

\begin{tabular}{lcc}
\hline Oxide composition & Rice husk ash (\%) & Coconut husk ash (\%) \\
\hline $\mathrm{MnO}$ & 0.19 & 0.005 \\
$\mathrm{CaO}$ & 0.02 & 0.29 \\
$\mathrm{~K}_{2} \mathrm{O}$ & 1.46 & 4.77 \\
$\mathrm{Fe}_{2} \mathrm{O}_{3}$ & 0.46 & 0.18 \\
$\mathrm{MgO}$ & 0.51 & 0.02 \\
$\mathrm{SiO}_{2}$ & 69.84 & 72.31 \\
$\mathrm{TiO}_{2}$ & 1.28 & 1.86 \\
$\mathrm{Al}_{2} \mathrm{O}_{3}$ & 1.28 & 0.86 \\
$\mathrm{P}_{2} \mathrm{O}_{5}$ & 0.26 & 0.60 \\
$\mathrm{Al}_{2} \mathrm{O}_{3}+\mathrm{Fe}_{2} \mathrm{O}_{3}$ & 1.74 & 1.04 \\
$\mathrm{SiO}_{2}+\mathrm{Al}_{2} \mathrm{O}_{3}+\mathrm{Fe}_{2} \mathrm{O}_{3}$ & 71.58 & 73.35 \\
$\mathrm{LOI}^{\mathrm{O}}$ & 8.24 & 9.34 \\
\hline
\end{tabular}


irreversible changes when oven dried at temperature of $\left.100-110{ }^{\circ} \mathrm{C}\right)$. They were subsequently subjected to grain size analysis, specific gravity and consistency limits tests in accordance with BSI 1377 (1990) test procedures with slight modifications where necessary to provide an understanding of their index properties and enable classification. For example, in the determination of grain size analysis wet sieving was adopted with about $500 \mathrm{~g}$ of air-dried crushed shale mixed with distilled water and calgon (deflocculating agent) stirred for about $20 \mathrm{~min}$ for effective dispersal of the soil grains. For completeness of investigation effective segregation of soil grains was achieved through constant agitation. The wet suspension was then passed through a $63 \mathrm{um}$ sieve to separate the coarse fraction from the fines fraction. CBR tests were performed on compacted samples in both unsoaked and soaked conditions. The CBR which is a semi empirical strength test is the ratio of the load that causes a penetration of 2.5 or $5.00 \mathrm{~mm}$ of a standard plunger in a sample to the standard load that causes similar penetrations of the same plunger respectively in a $13.24 \mathrm{KN}$ and 19.96 KN California sample. Readings of load taken at penetration intervals of 0.25$7.50 \mathrm{~mm}$ were plotted to generate a load deformation curve. Soaking of the samples in water was done for $24 \mathrm{~h}$ in accordance with the Nigerian general specification (Federal Ministry of Works and Housing 1997) before the determination of the soaked CBR to simulate natural conditions and assess the extent to which the ingress of water would expand and weaken the soils. Varying quantities of 2, 6, 10, 14 and $20 \%$ of both Rice husk and Coconut husk ash (by weight) separately was added to the shales and mixed thoroughly to allow for intimate mixing. The mixed samples were left for $48 \mathrm{~h}$ to cure and subsequently remixed to achieve a homogenous mix prior to compaction at Modified AASHTO level of compaction. The Modified AASHTO compaction was desirable because it is usually achievable with conventional field equipment. Moreover as indicated by Mohamedzein et al. (2005), shale can withstand higher energy level without mechanical instability. Hence compaction at Modified AASHTO was achieved using air dried samples weighing $6 \mathrm{~kg}$ mixed thoroughly with $6 \mathrm{~kg}$ of water. The material was compacted into a pre-weighed mould in 5 layers with each layer subjected to 55 blows of a $4.5 \mathrm{~kg}$ rammer falling through a height of $0.45 \mathrm{~m}$ uniformly. The process was repeated for all the five portions and then repeated after the addition of the ashes at 2, 6, 10, 14 and $20 \%$. In the determination of the UCS all the samples were cured for 7 days and were compacted at OMC to simulate field moisture compaction conditions. The samples compacted at OMC were taken in the form of cylinder which was later reduced to the required size of $76 \mathrm{~mm}$ long by $38 \mathrm{~mm}$ diameter and then loaded on the triaxial machine. The machine loads the cylindrical sample by moving the piston rod downward at a constant rate, after which the load that corresponds to the deformation were measured and read from a steel proving ring until the sample failed. Stress results were obtained through the applied force divided by cross sectional area of the sample while the strain was obtained through change in the original sample length. Calculations of stress and strain were plotted to determine the UCS. The consistency of the different mixtures was also determined to obtain the influence on plasticity index. Total abundances of the major oxides and several minor elements of the shale samples, rice husk ash (RHA) and coconut husk ash (CHA) were analysed by Induced Coupled Plasma-Emission Spectrometry (ICP-ES). The prepared samples were digested to complete dryness with an acid solution of (2:2:1:1) H2O-HF-HClO4-HNO3. $50 \%$ 
$\mathrm{HCl}$ was added to the residue and heated using a mixing hot block. After cooling the solutions were transferred to test-tubes and brought to volume using dilute $\mathrm{HCl}$ while sample splits of $0.25 \mathrm{~g}$ were analyzed. Furthermore the mineralogical composition of the soils was determined using X-Ray Diffraction (XRD) at the Acme Laboratories, Vancouver, Canada. Powdered samples of the soil were pelletized and sieved to $0.074 \mathrm{~mm}$. These were later mixed with acetone to produce a thin slurry and each sample mixture was applied to a glass was scanned through the Siemens D500 Diffractometer (using MDI Data Scan and JADE 8 softwares) for the determination of XRD.

\section{Results and discussion}

\section{Effect of RHA and CHA on Plasticity Index (PI)}

The addition of RHA to both the Okitipupa (SW) and Enugu (SE) shale caused a continuous reduction in PI up to $10 \%$ RHA. However, while the addition of $14 \%$ RHA brought about subsequent increase in PI for both shale types, only the SW shale showed consistency with continuous increase in all samples tested starting with the addition of $14 \%$ RHA as shown in Fig. 2 (Upper Section = SW and Lower Section = SE; CHA is represented by blue broken lines while RHA is represented by black continuous line). On the other hand for the SE shale, there was reduction in PI only up to $6 \%$ CHA addition after which PI increased up to $14 \% \mathrm{CHA}$ addition and later dropped with continuous increase in CHA content. Moreover, the response of the SW shale to the addition of $\mathrm{CHA}$ was haphazard and not the same for all the samples. Initial addition of $2 \%$ CHA resulted in PI reduction for 2 of the three samples while upon addition of $6 \%$ CHA, PI increased again. However optimum reduction in PI for all the samples of SW Shale was observed upon $10 \% \mathrm{CHA}$ addition. A reduction of plasticity is usually accompanied by reduced potential for swelling and hence an increase in strength properties. According to Obasi and Anyaegbunam (2005), soils of high plasticity are known to be composed of very small particles which having relatively high surface area per unit weight and possess a large number of particles contact points. On the other hand, soils of low plasticity, which have larger particles, possess a fewer number of inter-particle contact points. Soils with numerous contact point are thus
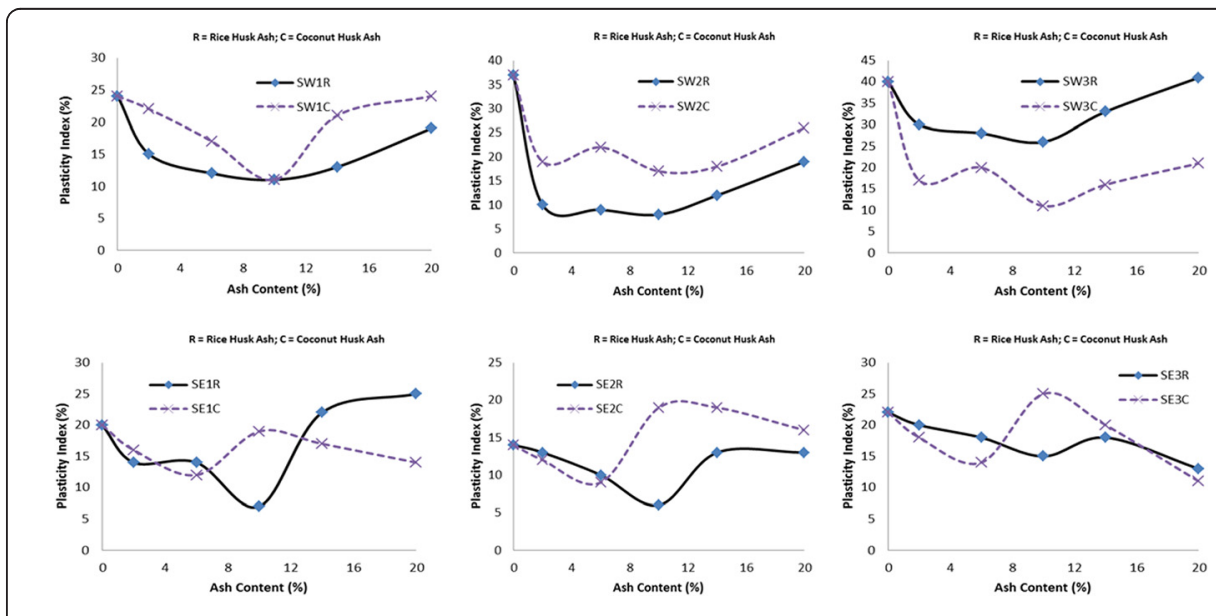

Fig. 2 Variation in PI of SW and SE shales with RHA and CHA addition 
expected to possess relatively lower average inter particle contact stress under an externally applied load. Hence the shear stress that can be mobilized to resist sliding would also be lower meaning soils with higher plasticity index (numerous contact points) will have a lower undrained shear strength than a soil with lower P.I. (fewer contact points). The reductions in PI are attributable to the replacement of the soil particles by RHA and CHA fines with consequent reduction in clay content and hence PI. This is because the plasticity of a soil decreases as the amount of clay fraction decreases and vice versa (Arora 2008). This reduction in PI is in agreement with results observed by other researchers (Rahman 1987; Basha et al. 2005; Okafor and Okonkwo 2009; Amu et al. 2011b; Eberemu et al. 2011) with separate use of either RHA or CHA to stabilize other soil types. The decrease in PI also indicates improved soil engineering properties. The maximum reduction in PI index (78 \%) for both the SW and SE shale was observed with the addition of RHA. In general, addition of $10 \%$ RHA and 6-10 \% CHA brought about optimal reduction in the plasticity of shale and as such can be regarded as the optimum content.

\section{Effect of RHA and CHA on compaction parameters}

Addition of up to $10 \%$ of RHA and CHA to SW and SE shales brought about increase in MDD as shown in Fig. 3. As the content of the additives increased, a corresponding increase in MDD was observed. However a reduction in MDD was noticed on increasing the content of both RHA and CHA by weight to $14 \%$. The increase in MDD may not be unconnected with the filling of the pores of the shales effectively with RHA and CHA. The decrease on the other hand is a sign of both RHA and CHA having less affinity for water, replacement of soil by RHA and CHA and the coating of the soil by the RHA which results to large particles with larger voids and hence less density (Osula 1991). An increase in MDD is a good indication of improvement in soil property. This increase in MDD further indicates the suitability of the energy of compaction and the fact that shales have been known to withstand higher energy of compaction. The result obtained with the use of CHA corroborates those reported by Amu et al. (2011b). The subsequent decrease in density may as indicated by Ola (1978) and Lees et al. (1982), be as a result of the flocculated and agglomerated clay particles in the shales occupying larger spaces leading to a corresponding decrease in dry density. The aggregation of

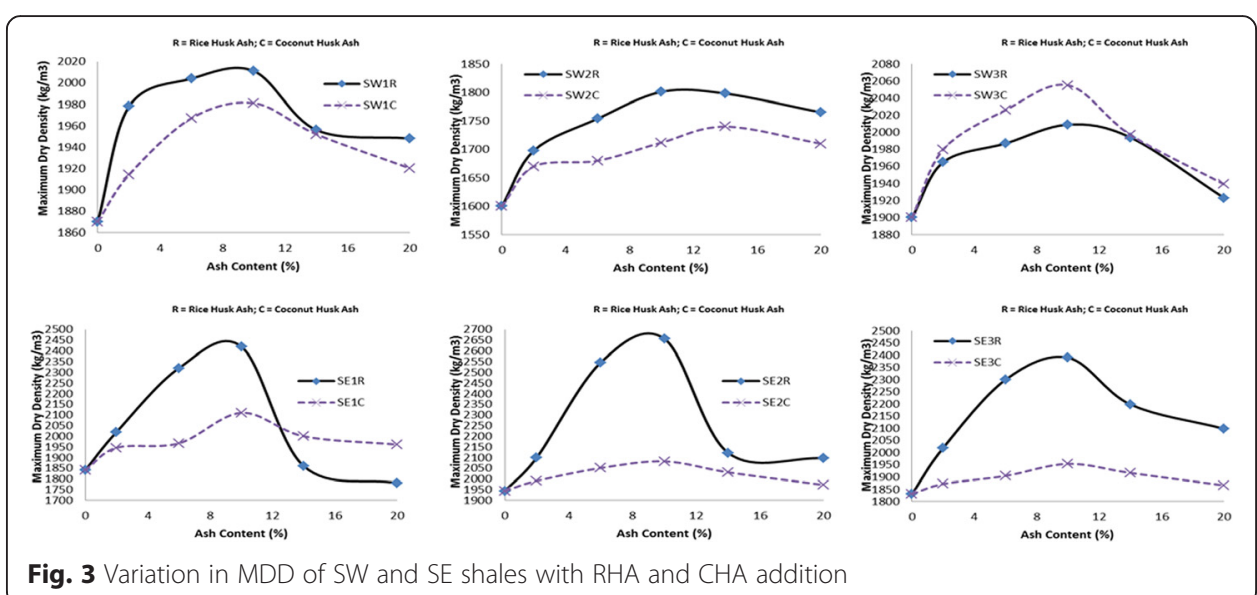


particles due to RHA and CHA which results in larger macropores within the soil may also be linked to the decrease. It is also opined that consideration of both RHA and CHA as fillers (with lower specific gravity) in the shale voids may also account for the decrease. As indicated by Nagaraj (1964) the subsequent decrease may be reflective of the increased resistance offered by the flocculated soil structure to the compactive effort. The opinion of Das (2000) revealed that a change down in dry density might occur due to both the particle size and specific gravity of the soil and stabilizer corroborating the assertion by Rahman (1987).

Furthermore, it was observed (as shown in Fig. 4) that an initial reduction in OMC occurred in all the shales with the addition of up to $10 \%$ RHA and CHA. This was followed by subsequent increase with the addition of $14 \%$ by weight of the additives. A reduction in OMC enhances the workability of a good soil. The increased OMC with increased RHA and CHA content from $14 \%$ may be as a result of the extra water required for the pozzolanic reactions and increased affinity for water. This may also be attributable to the additional water held within the flocculent soil structure. The additional water is accounted for as excess water absorbed or additional water being absorbed by the excess RHA and CHA as a result of its porous properties (Faisal et al. 1992; Zhang et al. 1996; Basha et al. 2005). The increased addition of RHA and CHA may also have resulted in decreased quantity of free silt and clay fraction and formation of coarser materials with larger surface areas which requires more water to take place (Osinubi 1999).

Furthermore it was observed that the increase in MDD with addition of RHA in all the shales was more pronounced than with the addition of CHA. In the same obvious fashion as observed with the MDD the addition of RHA had stronger effect on the OMC of the shales. The may be attributable to the more positive response of RHA to the compactive effort as opposed to CHA. A general pattern is observed in which the strength develops rapidly with addition of RHA and CHA until an optimum (10\%) is reached, beyond which the strength begins to decrease.

\section{Effect of RHA and CHA on Unconfined Compressive Strength (UCS)}

Sariosseiri and Muhunthan (2009) indicated that the Unconfined Compressive Strength (UCS) is widely used as an index to quantifying the effectiveness of an additive (improvement of soils due to treatment). The response of the two genetically different

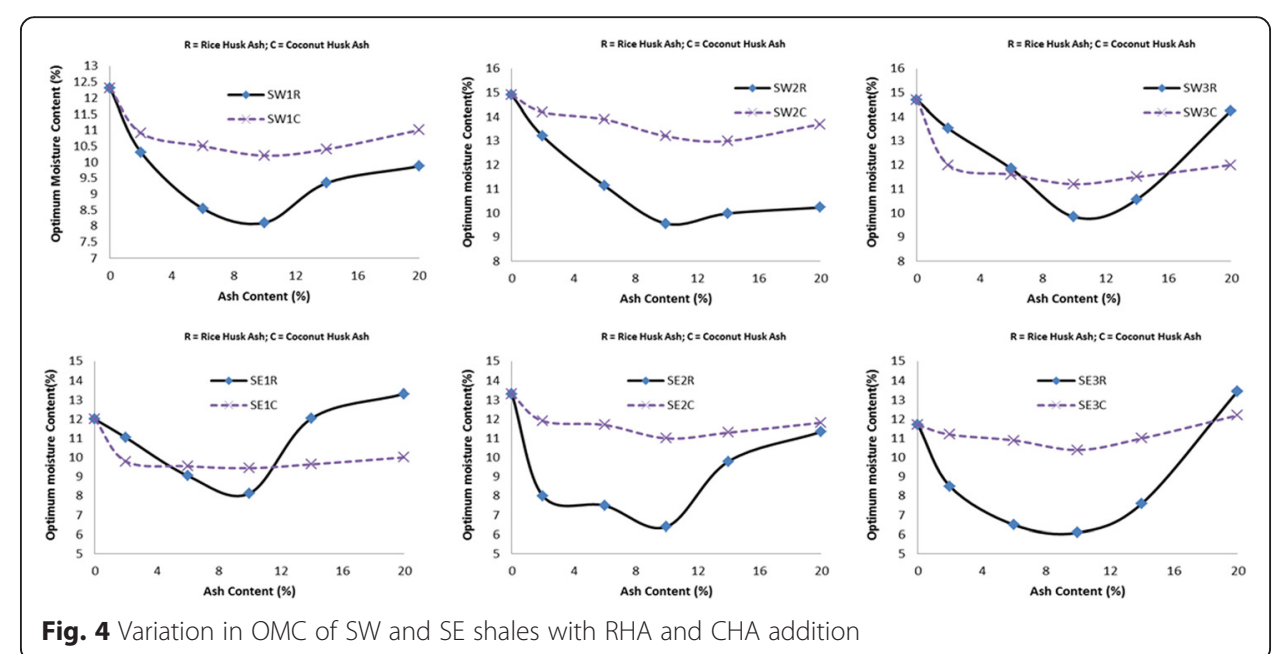


shale types to initial addition of both RHA and CHA was varied in terms of UCS. Addition of up to $20 \%$ of both RHA and CHA to SW shale yielded continuous increase in strength as shown in Fig. 5. The effect observed in this case, is similar to what was reported by Rahman (1987) with increasing addition of RHA. Bagheri et al. (2014) suggested that improvement in strength is due to the development of more cementation in the stabilized matrix. Chapman (1965) opined that the chemical reactions that occur (when RHA and CHA are mixed with shale) include pozzolanic reactions, cation exchange, carbonation and cementation. These result in agglomeration in large size particles resulting in compressive strength increase (Little et al. 2009). The increase in strength could also possibly be as a result of the increased pozzolanic reaction with increased RHA and CHA treatment which results in the formation of calcium silicate hydrates and increased strength. The situation can be explained based on the fact that these ashes are pozzolanic materials which would react in the presence of moisture to yield cementatious products (Malhotra and Mehta 2004). According to Brooks (2009), the high amount of silicon dioxide in RHA and CHA reacts with calcium for generating pozzolonic materials. The pozzolonic materials increase the strength of the shale-RHA/CHA blend. Eberemu (2011), on his own suggested that the increasing UCS can be attributed to the increasing RHA content changing the soil matrix with increasing fines, making it easier for the soil to be compacted. This increases the penetration by the compaction rammer on the soil surface resulting in closer alignment of particles along the failure surface.

On the other hand addition of $2 \%$ RHA and CHA to the SE shale brought about initial decrease in the UCS of the shale. An increase in UCS was only observed with the addition of $4 \%$ RHA and CHA and continued with addition up to $20 \%$. The initial decrease in the UCS of the SE shale is thought to be due to the reduction in the silt and clay content of the shale, which reduces the cohesion of the samples. The subsequent increment in the UCS after $2 \%$ RHA and CHA addition is attributed to the gradual formation of cementitious compounds between the additives and constituents contained in the shale. Another possible explanation for the initial decrease in UCS of the SE shale may be due to the mineralogy of the SE shale which includes the presence of pyrite. Pyrite which is the most common sulfide mineral is unstable as it is always being created or destroyed in nature and when exposed to air and water decomposes

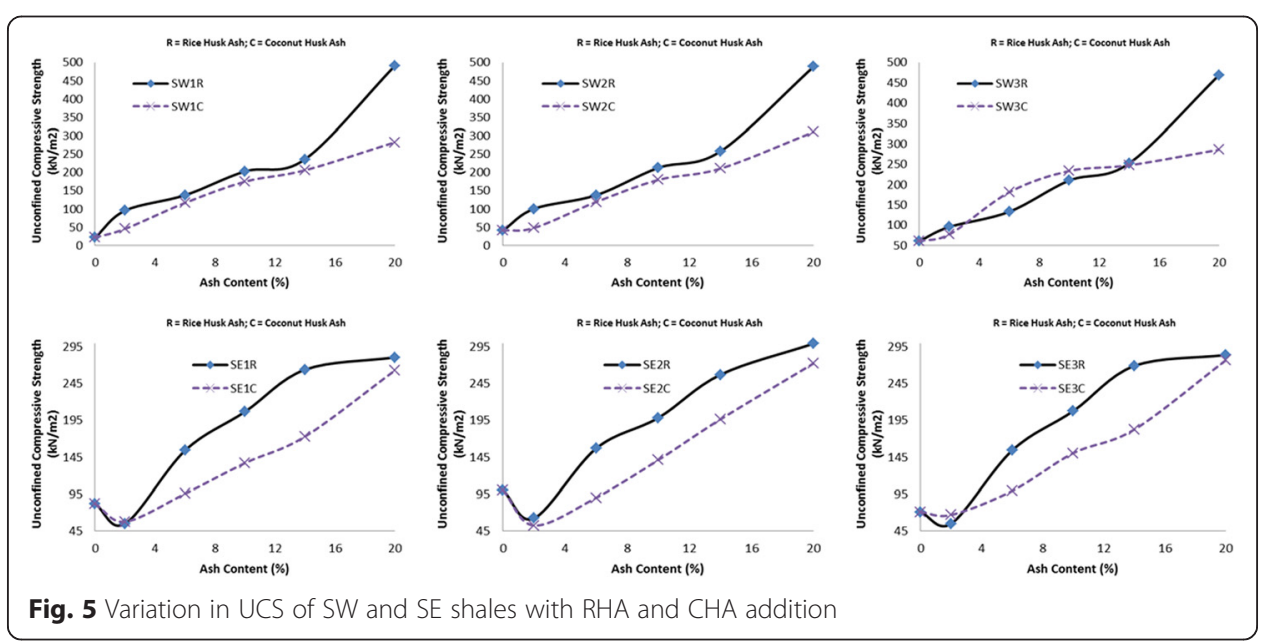


into iron oxides and sulfate eventually producing sulphuric acid. The presence of pyrites in aggregates used to make concretes have been known to lead to severe deterioration as the pyrite oxidizes (Tagnithamou et al. 2005; Anderson 2008).

The additives (RHA and CHA) can be said to have contributed to the strength development by acting as a microfiller and enhancer due to their increased reactivity and filler effect and have shown to be very effective additives to enhance the strength of tested shales. The addition of RHA however produced shales with higher UCS when compared with the CHA stabilized shales.

\section{Effect of RHA and CHA on California Bearing Ratio (CBR)}

As observed with the effect of RHA and CHA on UCS, the response of the two genetically different shale types to addition of both RHA and CHA was varied in terms of both unsoaked and soaked CBR. Addition of 2-20\% of both RHA and CHA to SW shale yielded continuous increase in unsoaked and soaked CBR (Figs. 6 and 7). CBR increment may due to the gradual formation of cementitious compounds in the shale by the reaction between the additives and the shale resulting in a well bonded mixture. This shows that the load bearing capacity of the shales increased considerably with both RHA and CHA. Rahman (1987) noticed a nonlinear increase in CBR for the admixtures. However with the SE shale, it was observed that although there was an initial increase in CBR up to $10 \%$ addition of both RHA and CHA, there was a subsequent decrease in both unsoaked and soaked CBR above 10 \% (Figs. 6 and 7). The decrease in CBR above $10 \%$ RHA and CHA content may be due to extra RHA and CHA that could not be mobilized for the reaction which consequently occupied spaces within the sample and reduced the bond in the shale-RHA/CHA mixtures.

\section{Conclusions}

Investigation into the strength characteristics of RHA and CHA compacted genetically different shales shows that they possess very high amounts of fines and are inorganic shales of medium plasticity and hence compressibility. The specific gravity obtained indicates materials which are non-durable as construction aggregates. They possess different mineralogy particularly with the SE shales which are black in colour
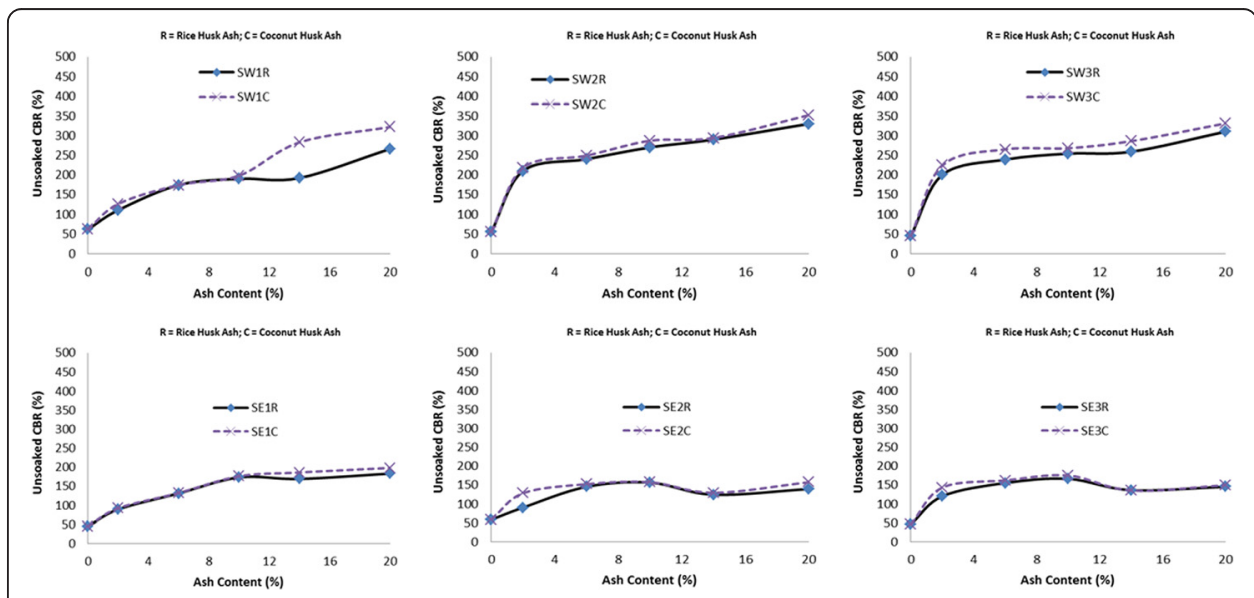

Fig. 6 Variation in CBR (unsoaked) of SW and SE shales with RHA and CHA addition 

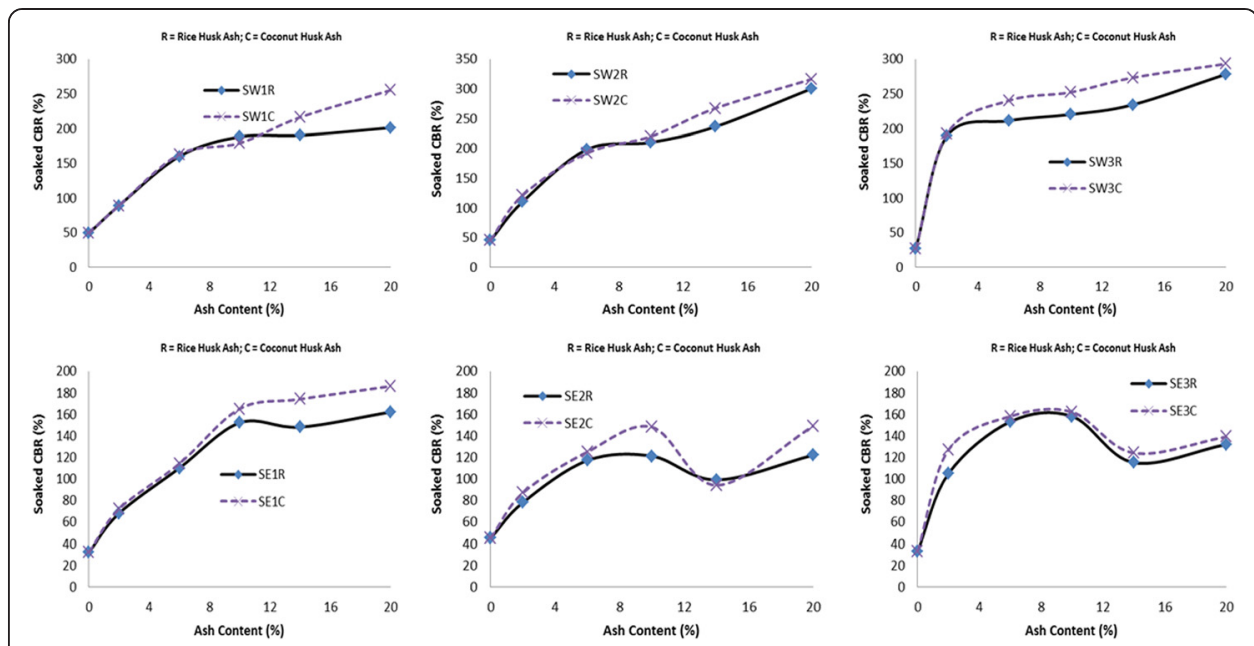

Fig. 7 Variation in CBR (soaked) of SW and SE shales with RHA and CHA addition

possessing some amounts of pyrite while the grayish SW shales contain in addition to kaolinite some amounts of albite.

Furthermore, RHA and CHA added to shale in modest amounts (not more than $10 \%$ by weight) has beneficial effect on the strength characteristics of the shales (with increased UCS, CBR, MDD and significant PI and OMC reduction due to their addition) in addition to possessing suitable pozolanic properties. They are thus viable, cost effective, environmental friendly, abundant options for modifying/stabilizing shales.

Moreover, addition of 10 \% RHA and 6-10 \% CHA generally brought about optimal effect on the geotechnical properties of shales and as such can be regarded as the optimum content. The addition of RHA however produced shales with reduced PI, higher UCS, increased MDD and more pronounced reduction in OMC when compared to the CHA stabilized shales.

Conclusively, the materials can serve as suitable alternatives to modify and stabilize problematic shale and hence help reduce construction costs, environmental hazards and ultimately bring about shales with improved geotechnical properties.

Competing interests

The authors declare that they have no competing interests.

\section{Authors' contribution}

OIA designed and supervised the research, monitored the experiments and drafted the manuscript while FOF carried out the experiments. All authors read and approved the final manuscript.

Received: 22 August 2014 Accepted: 24 August 2015

Published online: 10 September 2015

\section{References}

Abeyeskera, RA, Lovell, CW, \& Wood, LE. (1978). Stress deformation and strength characteristics of a compacted shale clay fills (pp. 1-14). London: Institution of Civil Engineers.

Agbede, IO, \& Joel, M. (2011). Effect of carbide waste on the properties of Makurdi shale and burnt bricks made from the admixtures. American Journal of Scientific and Industrial Research, 2(4), 670-673.

Akawwi, E, \& Al-Kharabsheh, A. (2002). Lime stabilization effects on geotechnical properties of expansive soils in Amman, Jordan. http://ejge.com/2000/Ppr0020/Abs0020.htm. (Accessed 18 December 2013).

Amu, OO, Oguniyi, SA, \& Oladeji, OO. (2011a). Geotechnical properties of lateritic soil stabilized with sugarcane straw. Ash American Journal of Scientific and Industrial Research, 2(2), 323-331.

Amu, OO, Ogunjobi, OA, \& Okhuemoi, Al. (2012). Effects of forage ash on some geotechnical properties of lime stabilized lateritic soils for road works. International Journal of Engineering and Technology, 2(4), 592-598. 
Amu, OO, Owokade, OS, \& Shitan, Ol. (2011b). Potentials of coconut shell and husk ash on the geotechnical properties of lateritic soil for road works. International Journal of Engineering and Technology, 3(2), 87-94.

Anderson, WH. (2008). Foundation problems and pyrite oxidation in the Chattanooga Shale, Estill County, Kentucky. Report of Investigations 18, Series XII, p.21.

Arora, KR. (2008). Soil mechanics and foundation engineering. Delhi: Standard Publishers Distributors.

ASTM C618-78. (1978). Specification for fly ash and raw or calcium natural pozzolana for use as a mineral admixture in Portland cement concrete.

Bagheri, Y, Ahmad, F, \& Ismail, MM. (2014). Strength and mechanical behavior of soil-cement-lime-rice husk ash (soil-CLR) mixture. Materials and Structures, 47, 55-66. doi:10.1617/s11527-013-0044-2.

Basha, EA, Hashim, R, Mahmud, HB, \& Muntohar, AS. (2005). Stabilization of residual soil with rice husk ash and cement. Construction and Building Materials, 19(6), 448-453.

Boateng, AA, \& Skeete, DA. (1990). Incineration of rice hull for use as a supplementary cementing material. The Guyana experience. Cement and Concrete Research, 20, 795-802.

Brooks, RM. (2009). Soil stabilization with flyash and rice husk ash. International Journal of Research and Reviews in Applied Sciences, 1(3), 209-217.

BSI 1377. (1990). Methods of testing soils for civil engineering purposes. London: Bristish Standards Institution.

Chapman, HD. (1965). Cation exchange capacity in methods of soil analysis (pp. 891-901). Madison: American society of Soil Agronomy, C.A. Black et al., Eds.

Coduto, DP. (1999). Geotechnical engineering, principles and practices. New Jersey: Prentice-Hall.

Das, BM. (2000). Fundamental of geotechnical engineering (4th ed.). USA: Thomson Learning.

Della, VP, Kühn, I, \& Hotza, D. (2002). Rice husk ash as an alternate source for active silica production. Materials Letters, $57,818-821$.

Eberemu, AO. (2011). Consolidation properties of compacted lateritic soil treated with rice husk ash. Geomaterials, 1, 70-78. doi:10.4236/gm.2011.13011.

Eberemu, AO, Amadi, AA, \& Sule, J. (2011). Desiccation effect on compacted tropical clay treated with rice husk ash. In J Han \& DE Alzamora (Eds.), Advances in geotechnical engineering (pp. 1192-1201). Opelika: Geotechnical Special Publication.

El-Sohby, MA, Shook, MA, \& Elleboudy, AM. (1987). Swelling and shear strength characteristics of Mokattan shale (Proc. 9th Regional Conference for Africa on Soil Mechanics and Foundation Engineering, Lagos, Nigeria, 15-18 September 1987, Vol. 1, pp. 143-6). Rotterdam: A. A. Balkema.

Ezeribe, IE. (1994). The characterization of some Nigeria shales relative to their engineering uses. Nsukka: Dissertation, University of Nigeria.

Faisal, HA, Aminuddin, A, \& Chew, KC. (1992). Use of rice husk ash to enhance lime treatment of soil. Canadian Geotechnical Journal, 29, 843-852.

Fattah, MY, Rahil, FH, \& Al-Soudany, KYH. (2013). Improvement of clayey soil characteristics using rice husk ash. Journal of Civil Engineering and Urbanism, 3(1), 12-18.

Federal Ministry of Works and Housing. (1997). Nigerian general specification for roads and bridges, Revised Edition, 2 (pp. 137-275).

Gamble, JC. (1971). Durability - plasticity classification of shales and other argillaceous rocks. Champaign: Dissertation, University of Illinois at Urbana.

Govindarao, VMH. (1980). Utilization of rice husk - a preliminary analysis. Journal of Scientific and Industrial Research, 39 , 495-515.

Holtz, RD, \& Kovacs, WD. (1982). Introduction to geotechnical engineering. New Jersey: Prentice-Hall.

Hughes, PN, \& Glendinning, S. (2005). Development of a soil mixing binder using waste materials. In 1st International Conference on Engineering for Waste Treatment: Beneficial Use of Waste and By-Products (WasteEng 2005), Albi, France.

Iorliam, AY, Agbede, IO, \& Joel, M. (2012a). Effect of cement kiln dust (CKD) on some geotechnical properties of black cotton soil (BCS). Electronic Journal of Geotechnical Engineering, 17(H), 967-77.

Iorliam, AY, Agbede, IO, \& Joel, M. (2012b). Effect of bamboo leaf ash on cement stabilization of Makurdi shale for use as flexible pavement construction material. American Journal of Scientific and Industrial Research, 3(3), 166-74.

Iorliam, AY, Okwu, P, \& Ukya, TJ. (2013). Geotechnical properties of Makurdi shale treated with bamboo leaf ash. AU Journal of Technology, 16(3), 174-180.

Joel, M, \& Agbede, IO. (2008). Effect of lime on some geotechnical properties of Igumale shale. Electronic Journal of Geotechnical Engineering, 13(A), 1-12

Krishnarao, RV, Subrahmanyam, J, \& Kumar, TJ. (2001). Studies on the formation of black particles in rice husk silica ash. Journal of the European Ceramic Society, 21(1), 99-104.

Lees, G, Abdelkater, MO, \& Hamdani, SK. (1982). Effect of the clay fraction on some mechanical properties of lime-soil mixtures. The Highway Engineer, 29(11), 2-9.

Little, DN, Males, EH, Prusinski, JR, \& Stewart, B. (2009). Cementitious stabilization. http://gulliver.trb.org/publications/ millennium/00016.pdf. (Accessed 14 October 2013).

Madjo, EK, \& Riskowiski, G. (2004). A procedure for processing mixtures of soil, cement, and sugar cane bagasse. Agricultural Engineering International. The Journal of Scientific Research and Development Manuscript BC 990, $111,1-5$.

Malhotra, VM, \& Mehta, PK. (2004). Pozolanic and cementitious materials. London: Taylor \& Francis.

Mehta, PK. (1977). Properties of blended cements made from rice husk ash. ACl Journal Proceedings, 74(9), 440-442.

Mitchell, JK. (1986). Practical problems from surprising soil behavior. Journal of Geotechnical Engineering, 112(3), 255-289.

Mohamedzein, A, Yahia, E, Amer, AA, Mohammed, YA, Ahmed, Q, \& Abdul-Hamid, A. (2005). Assessment of crushed shales for use as compacted landfill liners. Engineering Geology, 80, 271-281.

Nagaraj, TS. (1964). Discussion on Soil-lime research at lowa State University. ASCE Journal of the soil mechanics and foundations division, lowa State University, 90(SM6), 225-226.

Nagrale, SD, Hajare, H, \& Modak, PR. (2012). Utilization of rice husk ash. International Journal of Engineering Research and Applications, 2(4), 001-005 
Nakoo, Y. (1999). Rice: post harvest technology. Tokyo: ACE Corporation.

Nandi, A, Liutkus, CM, \& Whitelaw, MJ. (2009). Geotechnical characterization of Sevier and Rome shale, East Tennessee (Proceedings of the 43rd U.S. Rock Mechanics Symposium and 4th U.S. -Canada Rock Mechanics Symposium Special Volume, 1-8).

Nottidge, D.O., Balogun, R.B., Njoku, N.R. (2009). Effect of rice-husk ash on exchange acidity, growth and yield of groundnut (Arachis hypogaea I.) in an acid ultisol. Global Journal of Agricultural Sciences, 8(1). http://dx.doi.org/ 10.4314\%2Fgjass.v8i1.48514.

Obasi, NI, \& Anyaegbunam, AJ. (2005). Correlation of the undrained shear strength and plasticity index of tropical clays. Nigerian Journal of Technology, 24(2), 1-11.

Okafor, FO, \& Okonkwo, UN. (2009). Effect of rice husk ash on some geotechnical properties of lateritic soil. Leonardo Electronic Journal of Practices and Technologies, 15, 67-74.

Okogbue, CO, \& Aghamelu, OP. (2010). Comparison of the geotechnical properties of crushed shales from Southeastern Nigeria. Bulletin of Engineering Geology and the Environment, 69(4), 587-597.

Ola, SA. (1978). Geotechnical properties and behaviour of some stabilized Nigerian lateritic soils. Quarterly Journal of Engineering Geology and Hydrogeology, 11(2), 145-60.

Olarewaju, AJ, Balogun, MO, \& Akinlolu, SO. (2011). Suitability of eggshell stabilized lateritic soil as subgrade material for road construction. Electronic Journal of Geotechnical Engineering, 16(H), 899-908.

Oriola, F, \& Moses, G. (2010). Groundnut shell ash stabilization of black cotton soil. Electronic Journal of Geotechnical Engineering, 15, 415-428.

Osinubi, KJ. (1999). Evaluation of admixture stabilization of Nigeria black cotton soil. Nigeria Society of Engineers Technical Transactions, 34(3), 88-96.

Osula, DOA. (1991). Lime modification of problem laterite. Engineering Geology, 30, 141-149.

Oyetola, EB, \& Abdullahi, M. (2006). The use of rice husk ash in low - cost sandcrete block production. Leonardo Electronic Journal of Practices and Technologies, 8, 58-70.

Punmia, BC, Jain, AK, \& Jain, AK. (2005). Soil mechanics and foundations (16th ed.). New Delhi: Laxmi.

Rahman, MA. (1987). Effects of cement-rice husk ash mixtures on geotechnical properties of lateritic soils. Soils and Foundations, 27(2), 61-65.

Ramezanianpour, AA, Mahdi-khani, M, \& Ahmadibeni, G. (2009). The effect of rice husk ash on mechanical properties and durability of sustainable concretes. International Journal of Civil Engineering, 7(2), 83-91.

Reidenouer, DR. (1970). Shale suitability. Phase Il; Pennsylvania Department of Transportation, Bureau of materials, testing and research. Interim Report, No. 1.

Sariosseiri, F, \& Muhunthan, B. (2009). Effect of cement treatment on geotechnical properties of some Washington State soils. Engineering Geology, 104, 119-125.

Tagnithamou, A, Sariccoric, M, \& Rivard, P. (2005). Internal deterioration of concrete by the oxidation of pyrrhotitic aggregates. Cement and Concrete Research, 35, 99. doi:10.1016/j.cemconres.2004.06.030.

Yagiz, S. (2001). Overview of classification and engineering properties of shale for design considerations. In DE Hancher (Ed.), Proceedings of Second Congress on Construction and Materials Issues. American Society of Civil Engineers. Civil Engineering Conference and Expositions 2001 (pp. 156-165).

Zhang, MH, Lastra, R, \& Malhotra, VM. (1996). Rice husk ash paste and concrete: some aspects of hydration and the microstructure of the interfacial zone between the aggregate and paste. Cement and Concrete Research, 26(6), 963-977.

Zhang, MH, \& Malhotra, VM. (1996). High-performance concrete incorporating rice husk ash as a supplementary cementing material. ACI Materials Journal, 93(6), 629-636.

\section{Submit your manuscript to a SpringerOpen ${ }^{\circ}$ journal and benefit from:}

- Convenient online submission

- Rigorous peer review

- Immediate publication on acceptance

- Open access: articles freely available online

- High visibility within the field

- Retaining the copyright to your article 